\title{
Aplikasi SIG Untuk Pemetaan Zona Tingkat Bahaya Dan Keterpaparan Pemukiman Terhadap Tsunami Kota Denpasar
}

\author{
Oktaviana' ${ }^{1}$, Pegita Urmala Dewi', Mila Wahdini' ${ }^{1}$, Naira Prasiamratri', M. Budzar \\ Alghifarry $^{1^{*}}$, Nur Aulia Utami \\ ${ }^{1}$ Jurusan Teknik Geofisika, Fakultas Teknik, Universitas Lampung, Jl. Prof. Dr. Ir. Sumantri Brojonegoro, Bandar Lampung, \\ Lampung 35141
}

Dikirim:
10 April 2020
Direvisi:
5 Mei 2020
Diterima:
17 Juni 2020
*Email Korespondensi:
budzar81@gmail.com
A c) (1) (2)

Abstrak: Denpasar adalah ibukota provinsi Bali termasuk dalam wilayah terindikasi rawan tsunami karena berada didekat pinggir pantai serta memiliki ketinggian dan kemiringan yang relative kecil kepermukaan laut. Pemukiman merupakan aset wilayah yang harus dijaga. Sehingga zona keterpaparan pemukiman terhadap bahaya tsunami dibutuhkan guna memberikan informasi pada penduduk yang tinggal di kota tersebut. Tingkatan keterpaparan dilihat berdasarkan hazard dan element at risk. hazard ini dilihat berdasarkan jarakdari garis pantai, ketinggian, jarak dari sungai, dan juga kemiringan lereng dari daerah Denpasar ini, sedangkan Element at risk atau elemen yang terkena bencana tsunami nya ialah pemukiman. Pemetaan menggunakan teknik overlay, metode skoring dan pembobotan menggunakan software ArcMap 10.3 sebagai pendekatan berbasis Sistem Informasi Geografis (SIG). Hasil penelitian menunjukan bahaya didominasi tingkat sedang dan tinggi. tingkat keterpaparan tsunami pada pemukiman di kota Denpasar ini didominasi oleh tingkat keterpaparan sedang hingga tinggi dengan luas 3,46 km2 atau 27,21\% dari luas Kota Denpasar dan terpusat di Kec. Denpasar Timur (25,14 km2) dan Kec. Denpasar Barat (15,02 km2). Selain itu, pemukiman dengan keterpaparan tinggi yakni di Kec. Denpasar Selatan dengan luas 16,80 km2. Dikarenakan wilayah ketinggian yang rendah dan jarak dengan pantai dekat.

Kata kunci: Denpasar, overlay, pemukiman, SIG, tsunami

\begin{abstract}
Denpasar is the capital of the province of Bali, including an area prone to tsunamis because it is near the coast and has a relatively small height and slope to sea level. Settlements are regional assets that must be protected. So that the settlement zone for tsunami hazard is needed to provide information to the residents living in the city. The level of exposure is seen based on hazard and element at risk. This hazard is seen based on the distance from the coastline, altitude, distance from the river, and also the slope of the Denpasar area, while the element at risk or elements affected by the tsunami are settlements. Mapping using overlay techniques, suspension and weighting methods using ArcMap 10.3 software as an approach based on Geographic Information Systems (GIS). The results showed the danger was dominated by moderate and high levels. the level of tsunami exposure in settlements in the city of Denpasar is dominated by moderate to high levels of exposure with an area of $3.46 \mathrm{~km} 2$ or $27.21 \%$ of the area of Denpasar City and concentrated in Kec. East Denpasar (25.14 km2) and Kec. West Denpasar (15.02 km2). In addition, settlements with high exposure namely in Kec. South Denpasar with an area of $16.80 \mathrm{~km} 2$. Due to the region of low altitude and close distance to the beach.
\end{abstract}

Keywords: SIG, overlay, tsunami, settlement, Denpasar

\section{PENDAHULUAN}

Wilayah Indonesia berada diantara tiga lempeng dunia yaitu lempeng Indo-Australia, lempeng Eurasia dan lempeng Pasifik. Lempeng- lempeng tersebut mengalami pergeseran yang menyebabkan terjadinya gangguan di dasar laut. Gangguan tersebut dapat memicu terjadinya tsunami di Indonesia. Hal ini yang menjadikan Indonesia menjadi salah satu Negara yang memiliki ancaman terhadap bencana gempa bumi maupun tsunami. Indonesia telah banyak dilanda gempa merusak dan bahkan sering diikuti oleh gelombang tsunami yang dahsyat. Kepulauan di Indonesia mempunyai risiko besar terhadap gempabumi, dimana $80 \%$ dari wilayah Indonesia terletak di daerah seismik yang berisiko tinggi di dunia. (Nurjanah dkk, 2012)

Salah satu kota di Indonesia yang memiliki potensi terhdap gempabumi dan tsunami adalah Bali. Daerah Bali merupakan kawasan seismik aktif dan kompleks. Pengaruh tektonik utama Pulau Bali didominasi oleh tumbukan antara lempeng IndoAustralia dengan lempeng Eurasia. Tumbukan ini menyebabkan timbulnya pusat-pusat gempabumi di zona subduksi dan pusat-pusat gempabumi akibat patahan naik belakang busur di utara Bali. Daerah Bali sangat rawan terhadap gempabumi yang ditunjukkan dengan catatan sejarah gempabumi merusak pada masa lampau. Dengan demikian, daerah Bali juga rawan ancaman tsunami. (Pratama, 2017)

Pulau Bali termasuk dalam zona rawan. Seluruh kawasan pesisir pantai di Pulau Bali baik yang terletak di sebelah utara maupun di sebelah selatan merupaka zona rawan. Pantai selatan Bali berhadapan dengan zona subduksi lempeng, sedangkan pantai utara Bali berhadapan dengan sesar naik belakang busur kepulauan. Dalam hal ini, Kota Denpasar yang merupakan pusat kegiatan dan ibu kota Provinsi Bali tak luput dari ancaman tsunami. (BNPB, 2011) 
Menurut data indeks rawan bencana BNPB pada tahun 2011, kondisi topografi kota Denpasar memiliki ketinggian 0-75 meter dari permukaan laut. Topografi Kota Denpasar sebagian besar berupa dataran yang memiliki kemiringan lereng. Kota Denpasar merupakan kawasan yang memiliki risiko terhadap bencana tsunami. Menurut Fakhri dan Damayanti (2017), meningkatnya tingkat bahaya tsunami ini meningkatkan keterpaparan elemen berisiko bencana. Salah satunya yaitu permukiman, Kota Denpasar yang menjadi ibukota provinsi Bali ini memiliki aktivitas dan pemukiman yang cukup padat yang berada di pinggir pantai. Oleh karena itu, diperlukan pemetaan zona keterpaparan permukiman terhadap tsunami untuk menjaga penduduk yang berada di wilayah tersebut. Pemetaan keterpaparan permukiman terhadap tsunami ini juga dapat dijadikan sebagai acuan dalam mitigasi bencana dan meminimalkan kerugian akibat bencana tsunami. Upaya tersebut dapat dilakukan dengan memfokuskan mitigasi pada permukiman yang terpapar tinggi terhadap tsunami.

Pemetaan ini bertujuan untuk menaksir tingkat keterpaparan permukiman terhadap bencana tsunami. Keterpaparan menunjukkan sejauh mana elemen beresiko terkena oleh suatu bahaya tertentu di mana pada GIS digambarkan dengan mengoverlay peta bahaya dengan peta elemen beresiko. Tingkat keterpaparan dilihat dari dua komponen, yaitu tingkat bahaya (hazard), serta element at risk. Bahaya atau hazard merupakan kejadian fisik, fenomena atau aktivitas manusia yang berpotensi merusak yang dapat menyebabkan hilangnya nyawa atau cedera,

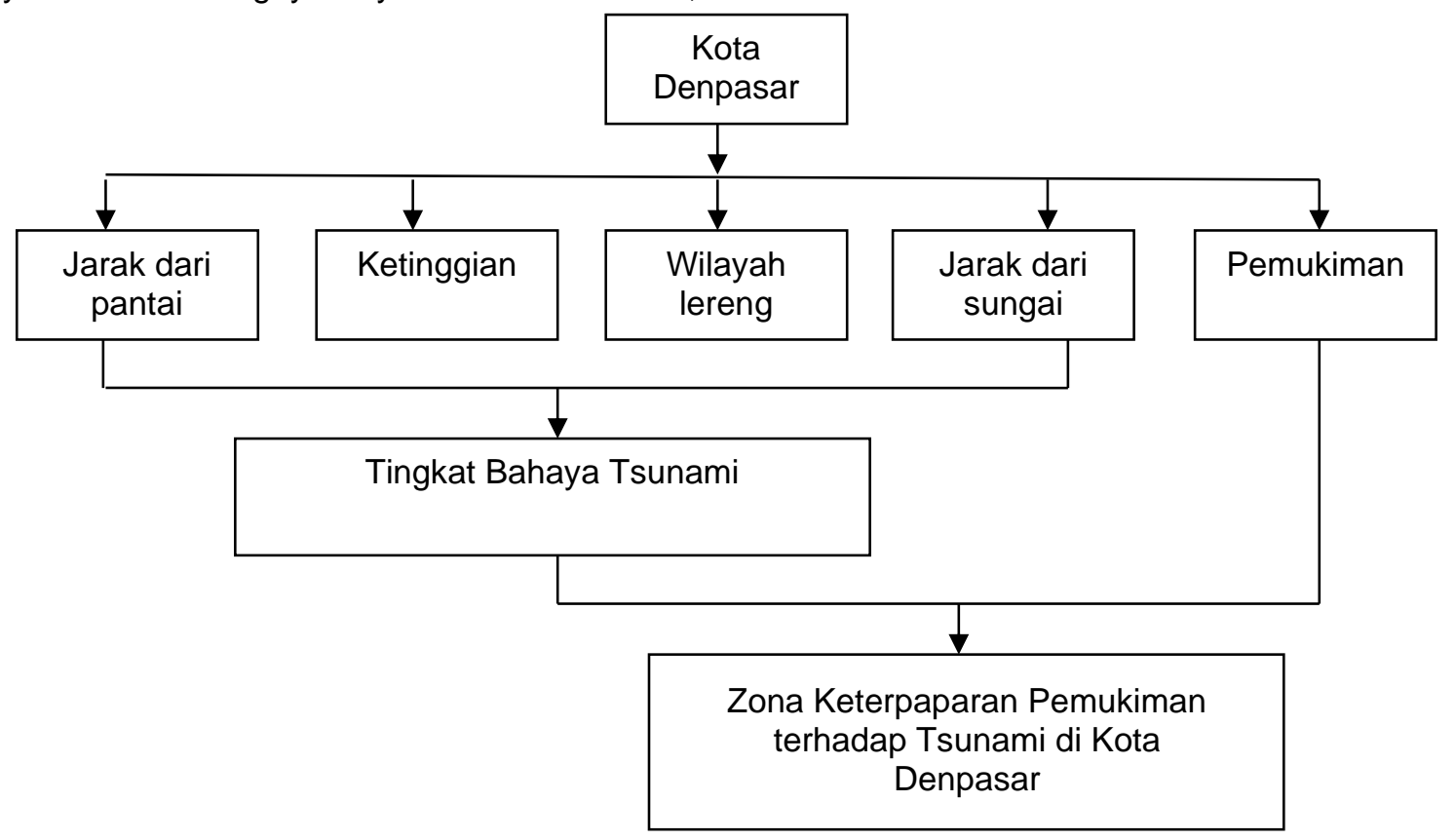

Gambar 1. Diagram Alir Faktor Keterpaparan Pemukiman Terhadap Tsunami

Data yang digunakan dalam penelitian ini terdiri atas data garis pantai, ketinggian, wilayah lereng, kerusakan properti, gangguan sosial dan ekonomi atau kerusakan lingkungan. Dilansir dari Mardiyanto, Bangun, Baskoro Rochaddi, dan Muhammad elmi pada tahun 2013 dalam Journal of marine research. Parameter yang digunakan dalam penentuan daerah rawan tsunami dengan pendekatan SIG meliputi: jarak dari sumber penyebab tsunami, morfologi dasar laut daerah pantai, elevasi lereng bawah laut, bentuk garis pantai, jarak dari sungai, keberadaan pulau penghalang, topografi daratan, elevasi daratan, keterlindungan daratan dan jarak dari garis pantai. Elemen yang terkena bencana atau element at risk merupakan populasi, properti, kegiatan ekonomi, termasuk layanan publik, atau nilai pasti lainnya yang terkena bahaya di wilayah tertentu. Element at risk dalam penelitian ini yaitu permukiman. (Pratama, 2017)

\section{BAHAN DAN METODE PENELITIAN}

Wilayah penelitian ini adalah kota Denpasar yang merupakan ibu kota provinsi Bali. Kota Denpasar terletak pada koordinat $08^{\circ} 35^{\prime} 31^{\prime \prime}-08^{\circ} 44^{\prime} 9^{\prime \prime}$ Lintang Selatan, $\quad 115^{\circ} 10^{\prime} 23^{\prime \prime}-115^{\circ} 16^{\prime} 27^{\prime \prime B u j u r}$ Timur. Menurut BPS kota denpasar, Tahun 2017. Denpasar memiliki penduduk sekitar 930.600 jiwa pada data tahun 2018 dengan luas wilayah 127,78 $\mathrm{km}^{2}$.Kota Denpasar terbagi kedalam 4 wilayah kecamatan yaitu, kecamatan Denpasar Selatan, Denpasar Utara, Denpasar Barat dan Denpasar Timur serta berbatasan dengan kabupaten Badung, kabupaten Gianyar dan Teluk Benoa. 
Denpasar yang diunduh dari website tanahair.indonesia.go.id. Data-data tersebut kemudian diolah dengan menggunakan software ArcMap 10.3. (Faiqoh, 2013).

Dalam penelitian ini dibagi menjadi dua bagian yaitu yang pertama penentuan tingkat bahaya tsunami, dan yang kedua penentuan tingkat keterpaparan permukiman terhadap tsunami. Untuk mengetahui dan menaksir tingkat bahaya tsunami dilakukan teknik overlay terhadap peta-peta tematik seperti peta jarak dari garis pantai, wilayah ketinggian, wilayah lereng, serta jarak dari sungai. Teknik overlay tersebut dilakukan dengan menggunakan metode skoring dan pembobotan. Menurut Subardjo petrus dan Raden ario pada tahun 2015 dalam jurnal kelautan tropis. Skoring dan pembobotan tersebut dilakukan untuk menentukan nilai bahaya. Setelah dilakukan penentuan tingkat bahaya tsunami, selanjutnya dilakukan penentuan wilayah permukiman yang terpapar oleh tsunami dengan meng-overlay peta bahaya tsunami tadi dengan peta permukiman menggunakan metode skoring dan pembobotan. Diagram alir penelitian ini dapat dilihat pada Gambar 1.

Tabel 1. Skor dan Bobot Tiap Parameter

\begin{tabular}{|c|c|c|c|}
\hline Parameter & Kelas & Skor & Bobot \\
\hline \multirow{5}{*}{ Jarak dari pantai } & $0-500 \mathrm{~m}$ & 5 & \multirow{5}{*}{30} \\
\hline & $501-1000 \mathrm{~m}$ & 4 & \\
\hline & $1001-1500 \mathrm{~m}$ & 3 & \\
\hline & $1501-3000 \mathrm{~m}$ & 2 & \\
\hline & $>3000 \mathrm{~m}$ & 1 & \\
\hline \multirow{5}{*}{ Ketinggian } & $<12 \mathrm{~m}$ & 5 & \multirow{5}{*}{30} \\
\hline & $13-30 \mathrm{~m}$ & 4 & \\
\hline & $31-45 \mathrm{~m}$ & 3 & \\
\hline & $45-64 \mathrm{~m}$ & 2 & \\
\hline & $>64 \mathrm{~m}$ & 1 & \\
\hline \multirow{5}{*}{ Wilayah lereng } & $0-2 \%$ & 5 & \multirow{5}{*}{25} \\
\hline & $3-5 \%$ & 4 & \\
\hline & $6-13 \%$ & 3 & \\
\hline & $13-20 \%$ & 2 & \\
\hline & $>20 \%$ & 1 & \\
\hline \multirow{5}{*}{ Jarak dari sungai } & $0-100 \mathrm{~m}$ & 5 & \multirow{5}{*}{15} \\
\hline & $101-200 \mathrm{~m}$ & 4 & \\
\hline & $201-300 \mathrm{~m}$ & 3 & \\
\hline & $301-500 \mathrm{~m}$ & 2 & \\
\hline & $>500 \mathrm{~m}$ & 1 & \\
\hline
\end{tabular}

Setelah peta bahaya tsunami diperoleh, selanjutnya peta bahaya tsunami tersebut dilakukan overlay dengan peta permukiman untuk melihat keterpaparan permukiman di Kota Denpasar terhadap bahaya tsunami. Peta pemukiman itu sebagai element at risk dalam penelitian ini. Data yang sudah diolah kemudian dianalisis dan diinterpretasikan menggunakan analisis spasial deskriptif. Untuk menggambarkan bagaimana persebaran wilayah atau zona bahaya tsunami dan keterpaparan permukiman terhadap bahaya tsunami di Kota Denpasar secara spasial atau keruangan (Hidayatullah, 2015).

\section{HASIL DAN PEMBAHASAN}

\subsection{Parameter Bahaya Tsunami}

Tingkatan bahaya tsunami bisa didasari oleh beberapa parameter diantaranya ada ketinggian, jarak dari garis pantai, wilayah lereng, serta jarak dari sungai, dikutib dari visualisasi resiko bencana milik Aditya tahun 2010, sementara untuk peta-peta tematik tersebut telah ditampikan sebagai berikut.
Seiring dengan bertambahnya jarak dari suatu tempat ke garis pantai maka akan semakin berkurang ketinggian gelombang tsunaminya dimana Jarak suatu tempat dari garis pantai dinilai sebagai parameter kerentanan bahaya tsunami berdasarkan pada jangkauan rayapan gelombang tsunami. Peta jarak dari garis Kota Denpasar pada Gambar 2 terdiri dari lima kelas. Wilayah yang berjarak 0-500 meter dari garis pantai memiliki tingkat bahaya tsunami yang tinggi. Pada wilayah yang berjarak 501-1000 meter dari garis pantai memiliki tingkat bahaya tsunami tertinggi kedua pada daerah Kota Denpasar. Pada wilayah yang berjarak 1001-1500 meter dari garis pantai yakni pada daerah Denpasar Timur memiliki kerentanan bahaya tsunami tidak terlalu tinggi. Pada wilayah yang berjarak 12001-3000 meter dari garis pantai yakni daerah Denpasar Utara memiliki tingkat bahaya yang rendah, sedangkan pada wilayah yang berjarak lebih dari 3000 meter memiliki tingkat bahaya yang sangat rendah karena jaraknya yang jauh dari garis pantai. 


\section{JARAK DARI GARIS PANTAI KOTA DENPASAR}

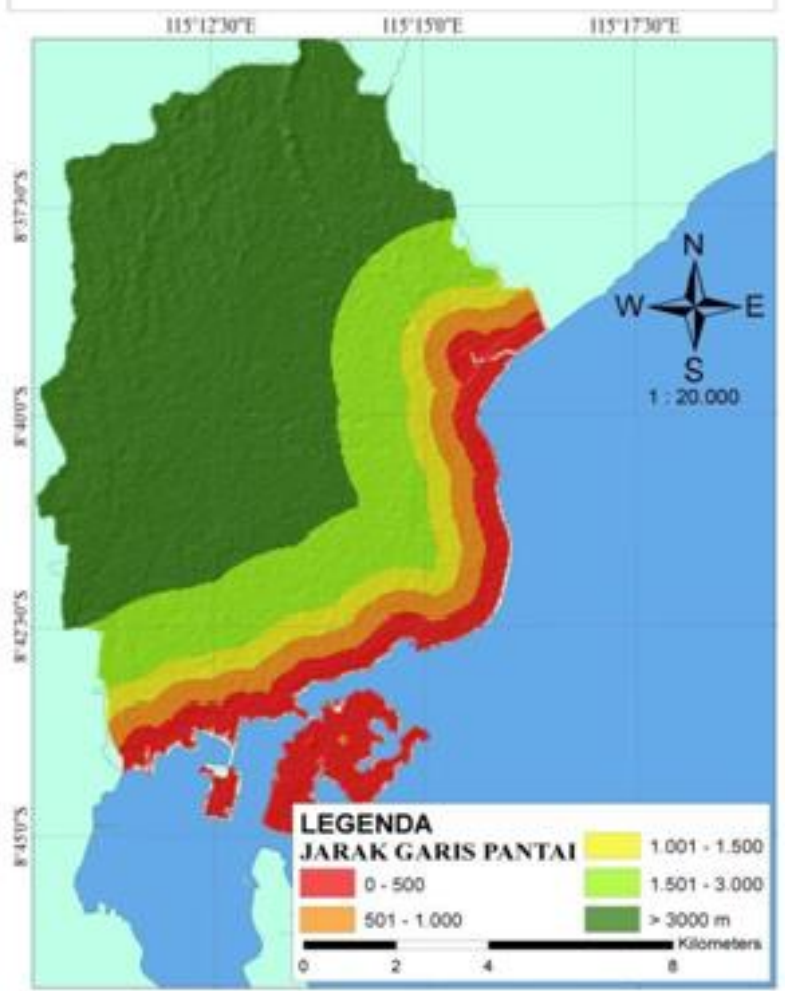

Gambar 2. Peta Jarak Garis Pantai

Jarak dari garis pantai memiliki hubungan yang berbanding terbalik dengan wilayah bahaya tsunami. Semakin dekat jaraknya dengan garis pantai maka semakin tinggi tingkat bahaya tsunaminya. Dan semakin jauh jaraknya dengan garis pantai maka semakin rendah tingkat bahaya tsunaminya. Berdasarkan pada data BNPB tahun 2012 dan juga dapat dilihat di peta tersebut diketahui bahwa Kota Denpasar didominasi oleh wilayah yang jaraknya lebih dari 3000 meter dari garis pantai.

Dilansir dari data pada BNPB tahun 2012 kota Denpasar memiliki rata-rata ketinggian yang terdiri dari lima kelas. Yaitu kelas yang pertama memiliki ketinggian dibawah $12 \mathrm{~m}$, lalu yang kedua $13-30 \mathrm{~m}$, yang ketiga wilayah yang memiliki ketinggian 31-45 $\mathrm{m}$, kelas keempat memiliki ketinggian 45-64 m, kelas yang terakhir wilayah yang memiliki ketinggian lebih dari $64 \mathrm{~m}$. Berdasarkan pada Gambar 3 kelas yang menunjukan paling rendah artinya daerah tersebut adalah daerah yang paling rendah di Kota Denpasar. Daerah paling rendah tersebut memiliki potensi tsunami paling tinggi, karena sangat rendahnya dataran tersebut akan menyebabkan tsunami akan menjadi leluasa untuk dapat masuk kedalam wilayah tersebut. Berdasarkan pada peta yang terlampirkan yang menunjukan mengenai wilayah ketinggian kota denpasar tersebut, kota denpasar didominasi oleh ketinggian dibawah 12 meter yang mana itu berarti ketinggian wilayah Denpasar tergolong masih rendah dan dapat diartikan bahwa kota Denpasar masih tergolong dalam wilayah rawan tsunami.

\section{WILAYAH KETINGGIAN KOTA DENPASAR}

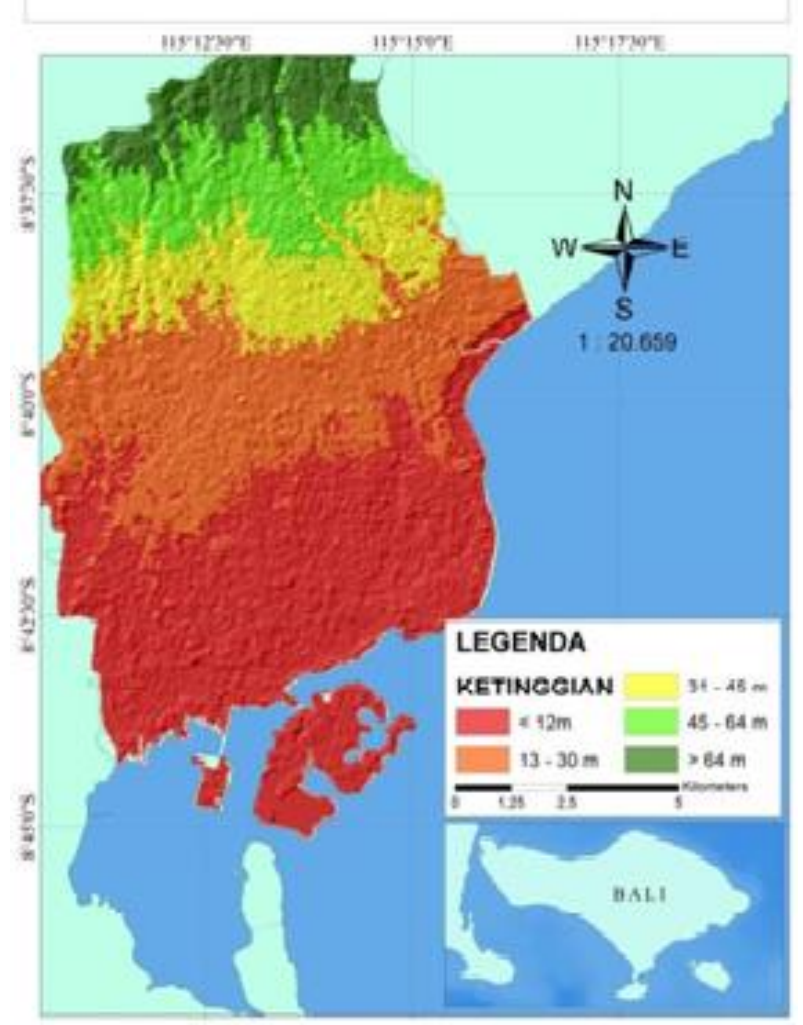

Gambar 3. Peta Wilayah Ketinggian

Berdasarkan peta pada Gambar 4, didapatkan informasi mengenai data kemiringan lereng Kota Denpasar yang dibagi sebanyak lima buah kelas yaitu, kemiringan 0\%-2\%, 3\%-5\%, 6\%-13\%, 13\%$20 \%$, dan $>20 \%$. Disini dapat disimpulkan bahwa kemiringan lereng yang ada pada wilayah Kota Denpasar didominasi oleh wilayah lereng dengan kemiringan antara $0 \%$ hingga $2 \%$ yang berarti memiliki kemiringan lereng yang landai atau datar. Dengan demikian, kemiringan lereng Kota Denpasar memiliki tingkat bahaya tsunami yang tinggi karena didominasi oleh wilayah lereng yang cukup landai, yang itu berarti wilayah landai tidaklah sanggup untuk menanggkal gelombang air laut yang datang dikarenakan tidak ada nya tanah sebagai media penghalang air laut tersebut karena kemiringan di wilayah denpasar dominan landai.

Untuk jarak dari sungai di kota Denpasar ini dibagi menjadi lima kelas, yakni 0-100 m, 101- 200 $\mathrm{m}, 201-300 \mathrm{~m}, 301-500 \mathrm{~m}$, dan $>500 \mathrm{~m}$ yang mana untuk kelas 0-100 meter dari sungai ini berada pada zona bahaya yang paling tinggi terhadap tsunami. Karena daerah sungai yang paling dekat laut akan memudahkan gelombang tsunami menerjang daratan. Dan untuk kelas jarak $>500$ meter dari sungai berada pada zona bahaya yang paing rendah karena jaraknya yang jauh dengan sungai. 
PETA KEMIRINGAN LERENG KOTA DENPASAR

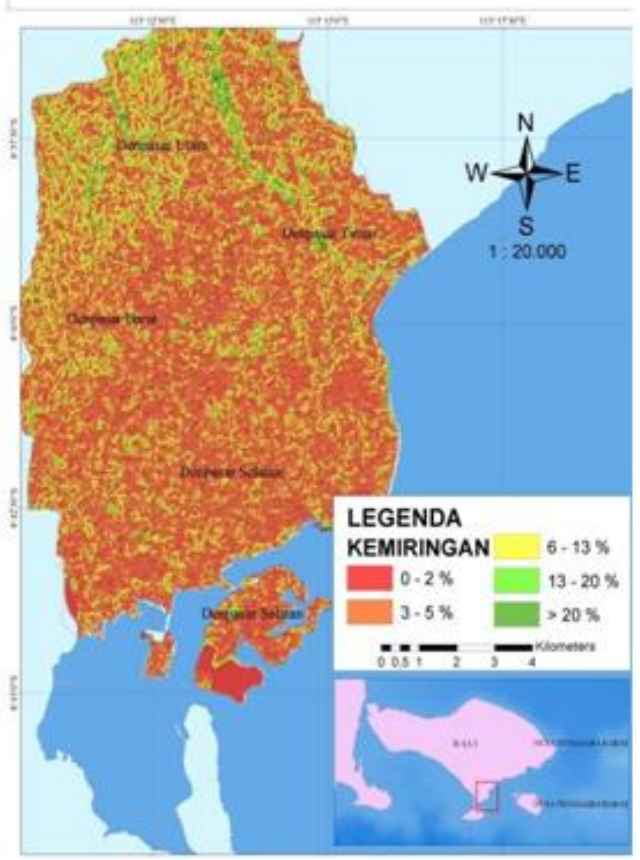

Gambar 4. Peta Kermiringan Lereng

Berdasarkan pada peta Gambar 5. Kota Denpasar tersebut didominasi oleh kelas 0-100 m

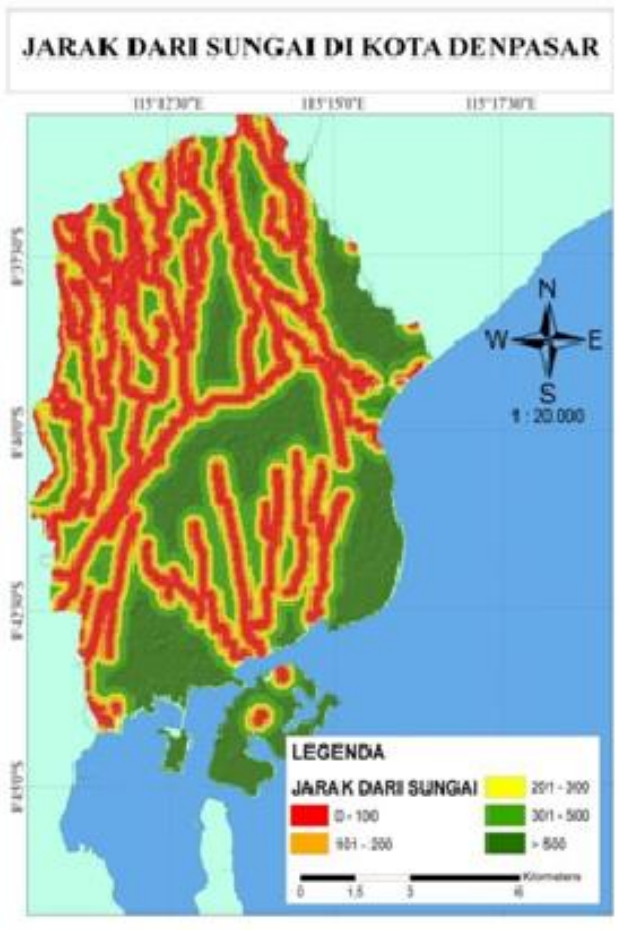

Gambar 5. Peta Jarak Sungai

yang artinya berdasarkan parameter jarak dari sungai Kota Denpasar memiliki bahaya tsunami yang tinggi.

Tabel 2. Luasan jarak dari garis pantai, ketinggian, wilayah lereng, dan jarak dari sungai di kota Denpasar

\begin{tabular}{cccc}
\hline \multirow{2}{*}{ Para-meter } & \multirow{2}{*}{ Kelas } & \multicolumn{2}{c}{ Luas } \\
\cline { 2 - 4 } & $0-500 \mathrm{~m}$ & 64,0735 & Persentase \\
\hline \multirow{3}{*}{ Jarak dari } & $501-1000 \mathrm{~m}$ & 27,0278 & 21,26 \\
pantai & $1001-1500 \mathrm{~m}$ & 6,3819 & 5,02 \\
& $1501-3000 \mathrm{~m}$ & 10,4373 & 8,21 \\
& $>3000 \mathrm{~m}$ & 19,2093 & 15,11 \\
\hline & $<12 \mathrm{~m}$ & 8,3918 & 6,601 \\
Ketinggian & $13-30 \mathrm{~m}$ & 16,2561 & 12,787 \\
& $31-45 \mathrm{~m}$ & 11,2026 & 8,812 \\
& $45-64 \mathrm{~m}$ & 32,4054 & 25,49 \\
& $>64 \mathrm{~m}$ & 56,5855 & 46,51 \\
\hline Kemiringan & $0-2 \%$ & 11,0875 & 8,72 \\
Lereng & $3-5 \%$ & 6,1912 & 4,87 \\
& $6-13 \%$ & 41,7876 & 32,87 \\
& $13-20 \%$ & 53,8141 & 42,33 \\
& $>20 \%$ & 14,2512 & 11,21 \\
\hline \multirow{2}{*}{ Jarak dari } & $0-100 \mathrm{~m}$ & 53,7505 & 42,28 \\
sungai & $101-200 \mathrm{~m}$ & 16,1455 & 12,7 \\
& $201-300 \mathrm{~m}$ & 4,6921 & 3,62 \\
& $301-500 \mathrm{~m}$ & 3,5723 & 2,81 \\
& $>500 \mathrm{~m}$ & 49,0594 & 38,59
\end{tabular}

\subsection{Tingkat Bahaya Tsunami}

Berikut ini telah dilampirkan sebuah peta yang berisikan informasi peta yang menunjukkan tingkat bahaya tsunami di Kota Denpasar, Berdasarkan Gambar 6 dapat diketahui bahwa Kota Denpasar didominasi oleh tingkat bahaya tsunami Sedang 
dan Tinggi. Hal ini juga bisa dilihat pada Tabel 3 yang menyatakan bahwa tingkat bahaya tsunami sedang mendominasi Kota Denpasar, yaitu seluas $5,47 \mathrm{~km}^{2}$ atau $42,8 \%$ dari luas Kota Denpasar, dan diikuti oleh tingkat bahaya tinggi seluas $4,72 \mathrm{~km}^{2}$ atau $36,98 \%$ dari luas Kota Denpasar.

Tabel 3. Luasan Tingkat Bahaya Tsunami di Kota Denpasar

\begin{tabular}{ccc}
\hline Tingkat & \multicolumn{2}{c}{ Luas } \\
\cline { 2 - 3 } Bahaya & Hektar & Persentase \\
\hline Rendah & 0,258 & 20,22 \\
\hline Sedang & 0,547 & 42,8 \\
\hline Tinggi & 0,472 & 36,98 \\
\hline
\end{tabular}

Tingkat bahaya tsunami di Kota Denpasar yang memilki tingkat bahaya tinggi sebagian besar berada di bagian Selatan Kota Denpasar, yaitu wilayah yang ketinggiannya rendah dan dekat dengan pantai. Selain itu, tingkat bahaya tsunami
Kota Denpasar yang rendah sebagian besar berada di bagian Utara Kota Denpasar, yaituwilayah yang ketinggiannya cukup tinggi dan jauh dari garis pantai.

Kecamatan yang memiliki tingkat bahaya tinggi terhadap tsunami yaitu Kec. Denpasar Selatan dan sebagian Kec. Denpasar Timur. Hal tersebut dikarenakan kedua kecamatan tersebut berbatasan langsung dengan garis pantai serta memiliki wilayah ketinggian yang cukup rendah. Kec. Denpasar Barat, dan sebagian Kec. Denpasar Timur juga Kec. Utara memiliki tingkat bahaya tsunami sedang. Karena ketiga daerah terbut jauh dari garis pantai dan memiliki ketinggian yang agak tinggi. Selain itu, untuk sebgaian Kec. Denpasar Utara memilki tingkat bhaya tsunami yang yang rendah karena sebagian dari Kec. Denpasar Utara memiliki wilayah yang cukup tinggi dan jauh dari garis pantai.

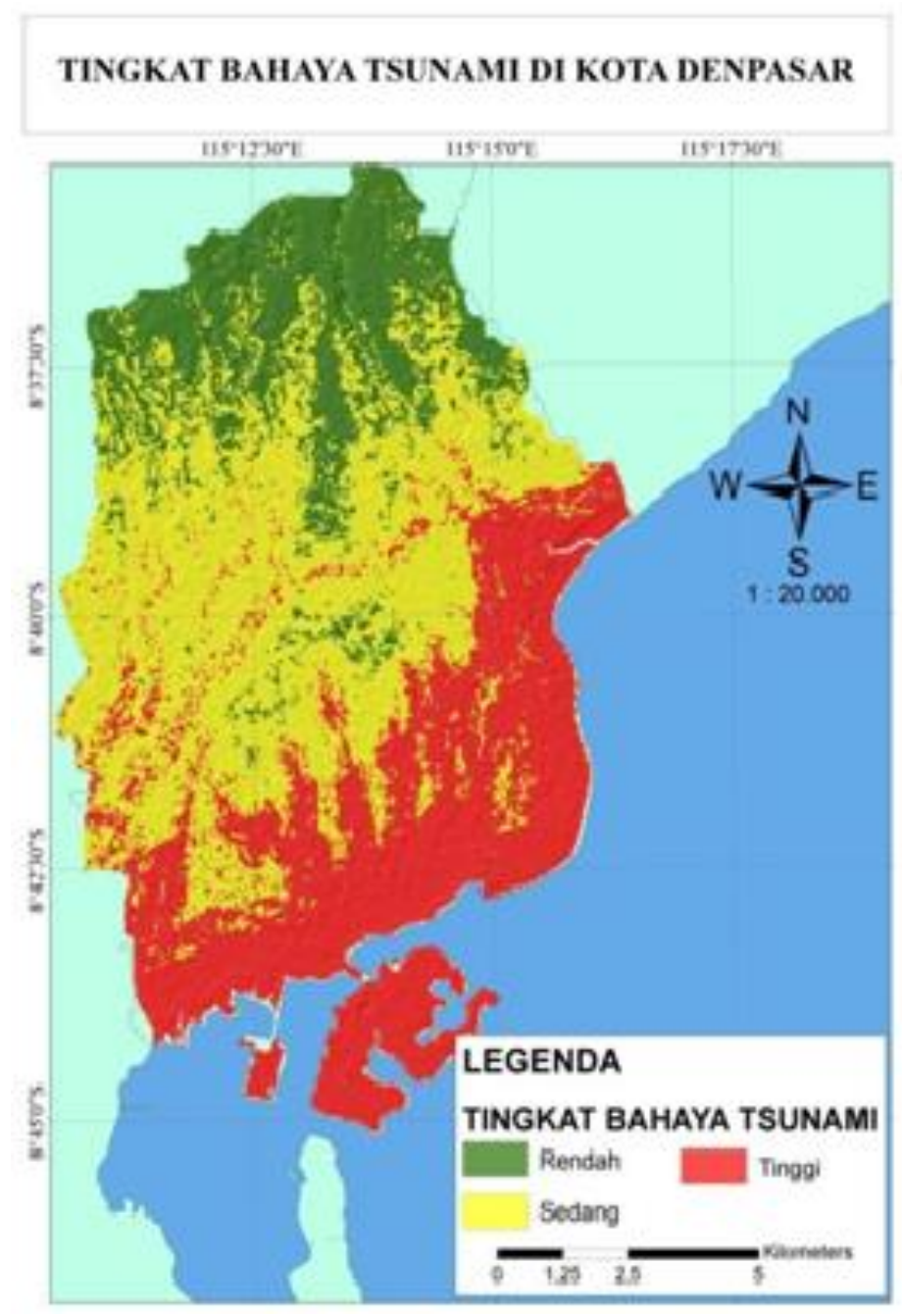

Gambar 6. Peta Tingkat Bahaya Tsunami

\subsection{Zona Keterpaparan Pemukiman Terhadap} Bahaya Tsunami Kota Denpasar

Berikut adalah peta yang menunjukkan tingkat bahaya tsunami di Kota Denpasar, Berdasarkan Gambar 6 dapat diketahui bahwa Kota Denpasar didominasi oleh tingkat bahaya tsunami Sedang dan Tinggi. Hal ini juga bisa dilihat pada Tabel $\mathbf{4}$ yang menyatakan bahwa tingkat bahaya tsunami sedang mendominasi Kota Denpasar, yaitu seluas $5,47 \mathrm{~km}^{2}$ atau $42,8 \%$ dari luas Kota Denpasar, dan diikuti oleh tingkat bahaya tinggi seluas $4,72 \mathrm{~km}^{2}$ atau $36,98 \%$ dari luas Kota Denpasar.

Available online at https://jgrs.eng.unila.ac.id/ DOI: https://doi.org/10.23960/igrs.2020.v1i2.28 
Tabel 4. Luasan Tingkat Bahaya Tsunami di Kota Denpasar

\begin{tabular}{ccc}
\hline Tingkat & \multicolumn{2}{c}{ Luas } \\
\cline { 2 - 3 } Bahaya & Hektar & Persentase \\
\hline Rendah & 0,258 & 20,22 \\
\hline Sedang & 0,547 & 42,8 \\
\hline Tinggi & 0,472 & 36,98 \\
\hline
\end{tabular}

Tingkat bahaya tsunami di Kota Denpasar yang memilki tingkat bahaya tinggi sebagian besar berada di bagian Selatan Kota Denpasar, yaitu wilayah yang ketinggiannya rendah dan dekat dengan pantai. Selain itu, tingkat bahaya tsunami Kota Denpasar yang rendah sebagian besar berada di bagian Utara Kota Denpasar, yaituwilayah yang ketinggiannya cukup tinggi dan jauh dari garis pantai.

Kecamatan yang memiliki tingkat bahaya tinggi terhadap tsunami yaitu Kec. Denpasar Selatan dan sebagian Kec. Denpasar Timur. Hal tersebut dikarenakan kedua kecamatan tersebut berbatasan langsung dengan garis pantai serta memiliki wilayah ketinggian yang cukup rendah. Kec. Denpasar Barat, dan sebagian Kec. Denpasar
Timur juga Kec. Utara memiliki tingkat bahaya tsunami sedang. Karena ketiga daerah terbut jauh dari garis pantai dan memiliki ketinggian yang agak tinggi. Selain itu, untuk sebgaian Kec. Denpasar Utara memilki tingkat bhaya tsunami yang yang rendah karena sebagian dari Kec. Denpasar Utara memiliki wilayah yang cukup tinggi dan jauh dari garis pantai.

Berdasarkan pada Gambar 7. Dapat diketahui tingkat keterpaparan permukiman di Kota Denpasar sebagian besar ada di wilayah dengan status wilayah "sedang" hingga "tinggi". Wilayah permukiman yang berada di tingkat keterpaparan tinggi terhadap tsunami tersebut didominasi oleh daerah di bagan Selatan Kota Denpasar dengan wilayah ketinggian yang cukup rendah dan dekat dengan garis pantai. Wilayah permukiman yang berada di tingkat keterpaparan sedang didominasi oleh wilayah pemukiman di kota Denpasar bagian barat dan timur dengan wilayah ketinggian yang agak tinggi serta agak jauh dengan garis pantai. Dan untuk wilayah pemukiman yang berada di tingkat rendah berada di bgian Utara Kota Denpasar karena wilayahnya yang tinggi dan jauh dengan garis pantai.

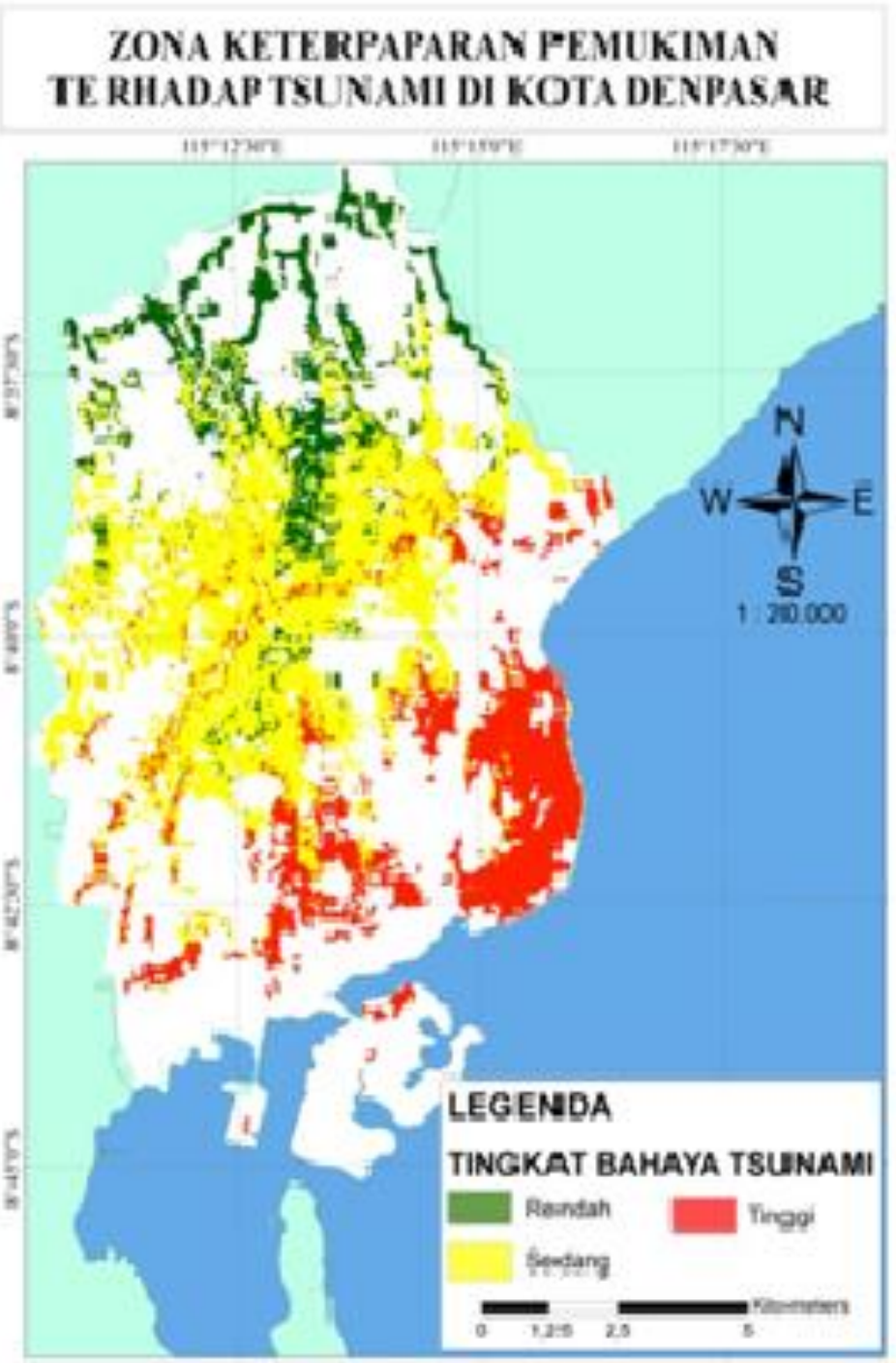

Gambar 7. Peta Zona Keterpaparan Permukiman Kota Denpasar Terhadap Tsunami 
Berdasarkan pada Tabel 5 dapat diketahui bahwa permukiman di Kota Denpasar didominasi oleh wilayah yang tingkat keterpaparan yang sedang yaitu seluas $3,46 \mathrm{~km}^{2}$ atau $27,21 \%$ dari luas Kota Denpasar. Diikuti oleh permukiman yang tingkat keterpaparannya tinggi seluas $2,08 \mathrm{~km}^{2}$ atau $16,29 \%$ dan permukiman yang tingkat keterpaparannya rendah seluas $1,22 \mathrm{~km}^{2}$ atau $9,67 \%$ dari luas Kota Denpasar

Tabel 5. Luasan Tingkat Keterpaparan Permukiman Terhadap Tsunami Kota Denpasar

\begin{tabular}{ccc}
\hline \multirow{2}{*}{ Tingkat } & \multicolumn{2}{c}{ Luas } \\
\cline { 2 - 3 } Keterpaparan & $\mathbf{K m}^{\mathbf{2}}$ & Persentase \\
\hline Rendah & 1,22 & 9,67 \\
\hline Sedang & 3,46 & 27,21 \\
\hline Tinggi & 2,08 & 16,29 \\
\hline
\end{tabular}

Berdasarkan pada Tabel 6 dapat diketahui bahwa kecamatan yang memiliki tingkat keterpaparan rendah terluas yaitu kecamatan DenpasarUtara, yaitu $19,05 \mathrm{~km}^{2}$. Dan luasan permukiman pada tingkat keterpaparan sedang yaitu didominasi oleh kecamatan Denpasar Timuryakni dengan luas $25,14 \mathrm{~km}^{2}$. Selanjutnya masih ditingkat sedang diikuti oleh Kecamatan Denpasar Barat seluas $15,02 \mathrm{~km}^{2}$, Selain itu, untuk tingkat keterpaparan tinggi, Kecamatan Denpasar Selatan merupakan wilayah dengan tingkat keterpaparan tinggi terluas, yaitu seluas $16,8 \mathrm{~km}^{2}$.

Tabel 6. Luasan Tingkat Keterpaparan Permukiman Terhadap Tsunami Kota Denpasar per Kecamatan

\begin{tabular}{ccccc}
\hline \multirow{2}{*}{$\begin{array}{c}\text { Tingkat } \\
\text { Keterpa } \\
\text { paran }\end{array}$} & $\begin{array}{c}\text { Denpa } \\
\text { sar } \\
\text { Barat }\end{array}$ & $\begin{array}{c}\text { Denpas } \\
\text { ar } \\
\text { Timur }\end{array}$ & $\begin{array}{c}\text { Denpa } \\
\text { sar } \\
\text { Utara }\end{array}$ & $\begin{array}{c}\text { Denpas } \\
\text { ar } \\
\text { Selatan }\end{array}$ \\
\hline Rendah & 3,80 & 13,67 & 19,05 & 1,91 \\
\hline Sedang & 15,02 & 25,14 & 10,25 & 5,04 \\
\hline Tinggi & 3,12 & 11,17 & 2,10 & 16,80 \\
\hline
\end{tabular}

Pemukiman di Kecamatan Denpasar Selatan didominasi oleh tingkat keterpaparan tinggi terhadap tsunami. Hal ini dikarenakan permukiman nya yang berada di dekat pantai, dan ketinggiannya yang cukup rendah. Permukiman di Kecamatan Denpasar Timur dan Denpasar Barat didominasi oleh tingkat keterpaparan sedang. Hal ini dikarenakan oleh wilayah ketinggiannya yang agak tinggi, dan pemukiman nya agak jauh dari garis pantai. Selain itu, pemukiman di Kecamatan Denpasar Utara didominasi tingkat keterpaparan rendah karena wilayahnya yang tinggi dan lokasi pemukiman nya yang jauh dari garis pantai.

\section{KESIMPULAN}

Berdasarkan pada Peta Tingkat Bahaya Tsunami di Kota Denpasar dapat diketahui bahwa Kota Denpasar berda di tingkat bahaya tsunami yang sedang hingga tinggi. Hal ini dilihat dari beberapa parameter seperti jarak dari garis antai, ketinggian wilayah, kemiringan lereng, dan jarak dari sungai. Parameter utama yang dilihat dari penentuan tingkat bahaya tsunami di Kota Denpasar ini adalah ketinggian wilayah, dan jarak dari garis pantai

Tingkat keterpaparan permukiman di Kota Denpasar didominasi oleh tingkat sedang hingga tinggi terhadap tsunami. Wilayah yang terpapar sedang terhadap tsunami seluas $3,46 \mathrm{~km}^{2}$ atau $27,21 \%$ dari luas Kota Denpasar terpusat di Kec. Denpasar Timur $\left(25,14 \mathrm{~km}^{2}\right)$ dan Kec. Denpasar Barat $\left(15,02 \mathrm{~km}^{2}\right)$. Selain itu, permukiman yang memiliki tingkat keterpaparan tinggi terhadap tsunami yakni di kecamatan Denpasar Selatan dengan luas $16,80 \mathrm{~km}^{2}$

\section{UCAPAN TERIMA KASIH}

Diucapkan terimakasih kepada semua pihak yang telah berkontribusi dalam pembuatan artikel ini, sehingga artikel ini dapat selesai dengan baik. Terutama kepada dosen pembimbing dalam pembuatan artikel ini.

\section{DAFTAR PUSTAKA}

Aditya, T. (2010). Visualisasi Resiko Bencana di Atas Peta. Yogjakarta: Fakultas Teknik Geodesi Universitas Gadjah Mada

Badan Pusat Statistik. (2017). Kota Denpasar Dalam Angka 2016. Badan Pusat Statistik (BPS) Kota Denpasar

BNBP. (2012). Peraturan Kepala Badan Nasional Penanggulangan Bencana Nomor 2 Tahun 2012 Tentang Pedoman Umum Pengkajian Risiko Bencana. Jakarta: 2012

BNPB. (2011). Indeks Rawan Bencana Indonesia. $B N P B$, Jakarta

Faiqoh, I., Gaol, J. L., \& Ling, M. M. (2013). Vulnerability Level Map of Tsunami Disaster in Pangandaran Beach, West Java . International Journal of Remote Sensing and Earth Sciences, 2(2), 90-103

Fakhri, H., \& Damayanti, A. (2017). Aplikasi SIG Untuk Pemetaan Zona Keterpaparan Permukiman Terhadap Tsunami, Studi Kasus: Kota Pariaman, Sumatera Barat. Prosiding Seminar Nasional Geomatika 2017, BIG.

Hidayatullah, S. S. (2015). Pemodelan Tingkat Risiko Bencana Tsunami Pada Permukiman di Kota Bengkulu Menggunakan Sistem Informasi Geografis. Jurnal Permukiman, 10(2), 92-105

Mardiyanto, B., Rochaddi, B., \& Helmi, M. (2013). Kajian Kerentanan Tsunami Menggunakan Metode Sistem Informasi Geografi di 
Kabupaten Bantul, Daerah Istimewa Yogyakarta. Journal of Marine Research, 10(2), 103-111

Mustafa, B. (2010). Lokasi Potensi Sumber Tsunami di Sumatera Barat. Jurnal IImu Fisika, 2(2), 94-100

Naryanto, H. S. (2007). Kajian Potensi dan Kegempaan di Liwa Kaitannya dengan Patahan Sumatera untuk Penataan Kawasan Berkelanjutan. Jurnal Alami, 12(2)

Nurjanah. (2012). Manajemen Bencana. Yogyakarta: Alfabeta.

Petrus, S., \& Ario R. (2015). Uji Kerawanan Terhadap Tsunami Dengan Sistem Informasi Geografis (SIG) Di Pesisir Kecamatan Kretek,
Kabupaten Bantul, Yogyakarta. Jurnal Kelautan Tropis, 18(2), 82-97

Pratama, W. S. (2017). Pemetaan Bahaya Tsunami Dan Dampaknya Terhadap Infrastruktur di Daerah Teluk Benoa Provinsi Bali. Skripsi. Fakultas Perikanan dan IImu Kelautan, Universitas Brawijaya. Malang.

Sengaji, E., \& Nababan, B. (2009). Pemetaan Tingkat Resiko Tsunami di Kabupaten Sikka, Nusa Tenggara Timur. Jurnal Ilmu dan Teknologi Kelautan Tropis, 1(1), 48-61

Tim Penyusun BNPB. (2012). Tanggap Tangkas Tangguh Menghadapi Bencana. BNPB: Jakarta 